\title{
Applied Research and Analysis of Construction of Foreign Language Learning Performance Model
}

\author{
Wu Boya, Liu Shuang \\ Dalian Maritime University, Dalian, Liaoning, 116000 \\ Criminal Investigation Police University of China, Shenyang, Liaoning, 110854
}

Keywords: foreign language; learning performance model; evaluation indicators

\begin{abstract}
Constructing foreign language learning performance model is conducive to understanding the main factors that affect the performance of foreign language learning. Consequently, foreign language learning can be carried out in an effective way based on the impact indicators. The paper uses AHP to determine the main influencing indicators of foreign language learning performance which includes language knowledge, motivation, language application ability, ability to adapt to the learning environment. In the meantime, the specific impacts of each indicator were analyzed.
\end{abstract}

\section{Introduction}

With the continuous development of information technology and the upgrade of mobile communication technology, the Ministry of Education has also stepped up its investment in new multimedia teaching methods for college English. Up to now, college multimedia practical teaching has formed a scale, mainly reflected as follows: mobile APP teaching, traditional desktop teaching and cloud service teaching. With the advent of big data, we will evaluate the effectiveness of online multimedia English teaching. These indicators include: financial input, human input, the economic benefits brought by learners to the society, and the input of teaching staff. In a word, it evaluates the performance of foreign language learning. The performance evaluation of foreign language learning only refers to learners' mastery of the grammar and vocabulary of foreign language, which can be applied to social studies, affective learning and cultural awareness [1]. The domestic research on the performance of online media foreign language learning starts relatively late. At present, the domestic and foreign research on foreign language learning performance model mainly includes: Literature [1] modeling the performance of network multimedia foreign language learning, and discussing the impact of performance factors through questionnaire survey. The results show that foreign language learning performance is influenced by four factors: the adaptability of the learning environment, the application of language knowledge, knowledge of language proficiency and the degree of language knowledge application. Literature [3] set up the performance theory of foreign language learning, and established a theoretical framework dominated by learning style theory, which can help foreign language learners. Literature [4] conducted relevant experiments to study the effects of learning mood and self-emotion of the freshmen in medical science on the performance level of foreign language learning. The results show that the impact factors of (1) medical freshman's learning performance of foreign language learning are: learning emotion and self-evaluation; (2) learning mood can be served to predict the performance of foreign language learning; (3) group counseling of self-concept can improve the performance of foreign language learning.

\section{Performance Evaluation Index and Model Construction of Foreign Language Learning}

Through the analysis of the current performance evaluation of foreign language learning, there are major problems: First, there are problems in defining the connotation of foreign language learning performance. The definition of performance connotation should meet the scientific 
requirements. At present, however, education in our country mainly focuses on exam-oriented education. The performance of foreign language learning is equivalent to that of foreign language test. In this situation, performance is often defined as test scores, making the standard too simplistic. The lack of sufficient attention to other factors such as the strategies and communicative competence of Internet multimedia environment learners is not included in the performance study. From the perspective of teaching practice, learners have a low motivation to learn and a single learning method, which is mainly based on examination, making it difficult to apply in practice. This is obviously not in line with the reform objective of the current education system. The reason why this phenomenon occurs is mainly due to the unscientific and reasonable definition of performance connotation. Second, the study of foreign language learning performance needs to be improved. At present, the study of foreign language learning performance is mainly based on speculative methods, and few of them are empirically studied. Although it also builds a performance model for foreign language learning, it still lacks empirical evidence. The lack of evidence is mainly due to the lack of data support, resulting weak explanations.

Table 1. Influencing Factors of Foreign Language Learning Performance Evaluation Indexes.

\begin{tabular}{|c|c|}
\hline first-level indicators & second-level indicators \\
\hline \multirow{5}{*}{$\begin{array}{lll}\text { Mastery of } & \text { Language } \\
\text { knowledge } & \end{array}$} & n 8 : Know common grammar knowledge. \\
\hline & $\begin{array}{l}\mathrm{n} 11 \text { : Grammar requirements of the textbook knowledge have } \\
\text { been mastered. }\end{array}$ \\
\hline & $\begin{array}{l}\mathrm{n} 13 \text { :In the process of writing and reading, students possess a } \\
\text { discourse structure knowledge system }\end{array}$ \\
\hline & n14: Understand some common vocabulary structures \\
\hline & $\begin{array}{l}\mathrm{n} 17 \text { : Learn the basic customs, history and knowledge of foreign } \\
\text { countries }\end{array}$ \\
\hline \multirow[t]{4}{*}{ learning motivation } & n5: Learn based on the future \\
\hline & $\mathrm{n} 12$ : Interested in the rich content of foreign language \\
\hline & n18 : Learning based on extended knowledge \\
\hline & n 21: Study for a higher score \\
\hline \multirow[t]{7}{*}{ language application ability } & $\begin{array}{l}\mathrm{n} 2 \text { : When reading foreign language materials, pay attention to } \\
\text { the coordination of speed control and understanding }\end{array}$ \\
\hline & $\begin{array}{l}\mathrm{n} 7 \text { : Solve problems in the classroom with obtained foreign } \\
\text { language knowledge }\end{array}$ \\
\hline & $\begin{array}{l}\text { n6 : Students can correctly express their own ideas, and } \\
\text { understand the meaning of others when Communicating with } \\
\text { people }\end{array}$ \\
\hline & $\mathrm{n} 10$ : Write with less Chinglish \\
\hline & $\mathrm{n} 16$ : Rethink what have been learned \\
\hline & n19 : Understand basic listening materials in class \\
\hline & $\begin{array}{l}\text { n } 20 \text { : Cultivate foreign language application with a focus on } \\
\text { communication }\end{array}$ \\
\hline \multirow{5}{*}{$\begin{array}{l}\text { ability to adapt to the learning } \\
\text { environment }\end{array}$} & $\mathrm{n} 1$ : $\quad$ Interested in classroom teaching with multimedia \\
\hline & n3 : Be able to create an English learning environment \\
\hline & $\begin{array}{l}\mathrm{n} 4 \text { : Be able to reach out for help through Internet when } \\
\text { encountering difficulties }\end{array}$ \\
\hline & $\begin{array}{l}\text { n9: Browse some foreign-language websites for language } \\
\text { learning }\end{array}$ \\
\hline & $\mathrm{n} 15$ : Use Internet to communicate with foreigners \\
\hline
\end{tabular}


Table 2. Survey Data.

\begin{tabular}{|c|c|c|c|}
\hline first-level indicators & second-level indicators & data & variance \\
\hline \multirow[t]{5}{*}{ F1 } & $\mathrm{n} 8$ & 0.811 & \multirow[t]{5}{*}{0.003} \\
\hline & $\mathrm{n} 11$ & 0.802 & \\
\hline & $\mathrm{n} 13$ & 0.787 & \\
\hline & $\mathrm{n} 14$ & 0.768 & \\
\hline & $\mathrm{n} 17$ & 0.772 & \\
\hline \multirow[t]{4}{*}{$\mathrm{F} 2$} & n5 & 0.712 & \multirow[t]{4}{*}{0.03} \\
\hline & $\mathrm{n} 12$ & 0.686 & \\
\hline & $\mathrm{n} 18$ & 0.802 & \\
\hline & $\mathrm{n} 21$ & 0.678 & \\
\hline \multirow[t]{7}{*}{ F3 } & $\mathrm{n} 2$ & 0.588 & \multirow[t]{7}{*}{0.08} \\
\hline & $\mathrm{n} 7$ & 0.676 & \\
\hline & n 6 & 0.662 & \\
\hline & $\mathrm{n} 10$ & 0.637 & \\
\hline & $\mathrm{n} 16$ & 0.633 & \\
\hline & $\mathrm{n} 19$ & 0.574 & \\
\hline & $\mathrm{n} 20$ & 0.521 & \\
\hline \multirow[t]{5}{*}{ F4 } & $\mathrm{n} 1$ & 0.817 & \multirow[t]{5}{*}{0.00005} \\
\hline & n3 & 0.796 & \\
\hline & $\mathrm{n} 4$ & 0.716 & \\
\hline & n9 & 0.548 & \\
\hline & $\mathrm{n} 15$ & 0.558 & \\
\hline
\end{tabular}

Based on the above research, the paper uses AHP combined with the practice of foreign language teaching in our university to build a network media foreign language learning model.

In the performance evaluation of foreign language learning, we cannot only focus on the student's test scores. With the development of quality education, it is necessary to expand the selection of performance evaluation indicators to fully reflect the students' performance in foreign language learning. Mastery of Language knowledge, learning motivation, language ability, ability to adapt to the learning environment are all indicators that affect the performance of foreign language learning, so the performance evaluation of foreign language learning is mainly based on the above four indicators. Assume that the above indicators are first-level indicators, denoted as F1, F2, F3 and F4. Secondary indicators should be set for each indicator. However, in order to understand the influence of each index on the performance evaluation of foreign language learning in detail, this paper mainly uses the questionnaire method to investigate and analyze the influencing factors of the second-level index based on the four first-level indicators. Therefore, the secondary indicators are mainly based on the questionnaire. Table 1 shows the composition of the influencing factors.

When the eigenvalue of the first level indicator is greater than or equal to 1 , it indicates that the eigenvalue is within the acceptable range. Through data analysis, we can see that the load of each 
index is mainly located between $0.521-0.817$, both far greater than 0.3 . Therefore, through this data analysis, we can see that the foreign language learning performance scale has a good institutional validity. At the same time it shows that these four first-level indicators can reflect the characteristics of foreign language learning performance evaluation.

\section{Results of Application of Foreign Language Learning Performance Model}

Through the above performance model construction and analysis, we can see that mastery of language knowledge, learning motivation, language ability, and ability to adapt to the learning environment are important evaluation indexes of foreign language learning performance. Through analysis of second-level indicators, we can understand the situation of students' foreign language learning.

(1) Mastery of language knowledge: as to mastery of language knowledge, students have a good grasp of vocabulary and basic vocabulary required in textbooks. However, many students mainly focus on lexical learning while learning; the grammar is boring and difficult to understand, making many students learn nothing from grammatical learning; while many students have mastered the total-sub-total structure in discourse learning; with the aid of Internet, students can obtain a broad knowledge, and have a strong interest in learning foreign customs.

(2) Learning motivation: as to motivation in learning, many students learn language for getting high marks, especially for students in the lower grades. While senior students continue to learn foreign languages after they have completed their credits, mainly because of their interest. However, on the whole, the motivation of taking scores as the main is typical examination-oriented education.

(3) Language application ability: The purpose of language learning is to apply it in practice. However, we can see from the analysis that at present many students lack the ability of language application and cannot be well applied in practice, especially in listening and speaking, and cannot meet the daily communication requirements.

(4) Ability to adapt to the learning environment: At present, many language study class is carried out in the form of multimedia, making students willing to learn foreign language. However, students do not have a good learning environment during their daily study. They do not recognize the importance of Internet, and seldom use foreign language websites, or take the initiative to create a foreign language learning environment, which hinders their foreign language learning.

Through the above analysis, it can be concluded that in the foreign language learning, many students still attach importance to the cultivation of knowledge learning but neglect skills cultivation. Students mainly use the foreign language as a learning tool and fail to take the initiative to create a good learning environment, thereby affecting the improvement of foreign language learning performance.

\section{References}

[1] Qin Xiaoqing. Quantitative Data in Foreign Language Teaching and Research [M]. Huazhong University of Science and Technology Press, 2004.

[2] Guo Xingang. Correlation Study on freshmen's Self - concept, Academic Emotions and Foreign Language Learning Performance in Medical University [D]. Shanxi Medical University, 2016.

[3] Wang Xiaogen, Wang Lili, Wu Renchang. Research on the Performance Evaluation Index of Chinese Reading Multimedia Teaching Based on Analytic Hierarchy Process [J]. Electrification Education Research, 2013970: 87-93. 